\title{
HOW MUCH DO BELIEF AND CULTURAL FACTORS AFFECT THE INCIDENCE OF EARLY MARRIAGE? A NEW PATH ANALYSIS EVIDENCE FROM NGAWI, EAST JAVA
}

\author{
Noviana Ayumi Wijayati'1), RB. Soemanto'2), \\ Ety Poncorini Pamungkasari3)
}

\author{
1) Masters Program in Public Heath, Universitas Sebelas Maret \\ 2) Faculty of Social and Political Sciences, Universitas Sebelas Maret \\ 3) Department of Public Health, Faculty of Medicine, Universitas Sebelas Maret
}

\begin{abstract}
Background: Indonesia ranks 37 of the countries in the world with the highest rate of early marriage. Early marriage in Indonesia occurs more frequently in rural areas. Studies have shown, West Sulawesi experiences the highest rates of child marriage before the age of 15 , where the practice is a deeply entrenched cultural tradition. The center for Gender and Sexuality Studies, University of Indonesia reported in 2015 that Indonesia rank the second highest rate of early marriage in South East Asia. Approximately 2 millions (7.3\%) girls aged under 15 years old have been married and dropped out of school. This number is expected to become 3 million married girls in 2030. This study aimed to determine the effect of socioeconomic and cultural factors on early marriage in Ngawi, East Java.
\end{abstract}

Subjects and Method: This was a case control study conducted in Ngawi, East Java. A sample of 75 women of reproductive age who got married before 20 years old and 75 women of reproductive age who got married had 20-30 years of age. The dependent variable was early marriage. The independent variables were paternal education level, maternal education level, family income, family belief, culture, and peer group. The data were collected by a set of questionnaire and analyzed by path analysis model.

Results: The incidence of early marriage increased by favorable family belief $(b=$ $1.47 ; 95 \% \mathrm{CI}=0.44$ to $2.50 ; \mathrm{p}=0.005)$ and favorable culture $(\mathrm{b}=1.56 ; 95 \% \mathrm{CI}=$ 0.54 to $2.58 ; \mathrm{p}=0.003)$, but decreased by high family income $(\mathrm{b}=-2.20 ; 95 \% \mathrm{CI}=$ -3.18 to $-1.21 ; \mathrm{p}<0.001)$, and positive peer group $(\mathrm{b}=-2.51 ; 95 \% \mathrm{CI}=-3.58$ to -1.44 ; $\mathrm{p}<0.001)$. The incidence of early marriage was indirectly affected by paternal education and maternal education.

Conclusion: The incidence of early marriage is directly affected by family belief, culture, positive peers, and family income. The incidence of early marriage is indirectly affected by paternal education and maternal education.

Keywords: early marriage, family belief, culture, peers, family income, parental education

\section{Correspondence:}

Noviana Ayumi Wijayati. Masters Program in Public Heath, Universitas Sebelas Maret, Jl. Ir. Sutami 36 A, Surakarta 57126, Central Java.

Email: novianaayumi@gmail.com. Mobile: +6285645828766. 